\title{
Phytogenic additives and organic acids in broiler chicken diets
}

\author{
Vitor Barbosa Fascina ${ }^{1,2}$, José Roberto Sartori ${ }^{1}$, Elisabeth Gonzales ${ }^{1}$, Fabyola Barros de \\ Carvalho', Ivan Mailinch Gonçalves Pereira de Souza, ${ }^{1,2}$, Gustavo do Valle Polycarpo', \\ Ana Cristina Stradiotti ${ }^{1}$, Vanessa Cristina Pelícia ${ }^{1}$
}

\footnotetext{
${ }^{1}$ Universidade Estadual Paulista, Faculdade de Medicina Veterinária e Zootecnia, Caixa Postal 560, CEP: 18618-000, Botucatu, SP. ${ }^{2}$ FAPESP grant holder.
}

\begin{abstract}
The experiment evaluated the influence of isolated or associated phytogenic additives (PA) and organic acids $(\mathrm{OA})$ on nutrient digestibility, performance and carcass characteristics of broiler chickens. Two experiments were conducted in a completely randomized design with a $2 \times 2+1$ factorial arrangement of treatments (with or without PA $\times$ with or without OA + antibiotic performance enhancer and anticoccidial). In the first experiment, two metabolic tests were conducted to determine the metabolizability coefficients of the nutrients of starter and growth diets. In the second experiment, 2520 one-day-old chicks were housed in 40 experimental units to evaluate the performance and carcass characteristics. The phytogenic additives and organic acids, isolated or associated, improve the nutrient digestibility of the diet and replace the growth-promoting antibiotics. The use of organic acids isolated or associated with phytogenic additives in broiler diets improves broiler performance in comparison with free antibiotic performance enhancer at 42 days of age. Isolated or associated phytogenic additives and organic acids provided better carcass characteristics.
\end{abstract}

Key Words: acidifier, additive, antibiotics, herbal extract, metabolism, sanitary challenge

\section{Introduction}

The selection of premature birds and the major housing density has intensified health problems and denouncements of slaughterhouses, reflecting the increased use of antibiotic performance enhancer (APE), and the therapeutic use of anticoccidial and chemotherapy. However, the consumer market of Brazilian meat, especially the European Union, has banned the use of APE.

Phytogenic additives (PA) from plant extracts are an alternative to APE because they promote higher nutrient digestibility, increase digestive enzyme activity and gastric and pancreatic juice secretion, protect the intestinal microvilli and improve bird performance by antimicrobial activity (Hernández et al., 2004; Toledo et al., 2007).

Another alternative to APE are organic acids (OA), which have shown positive results in poultry production, for reducing the intestinal $\mathrm{pH}$ and bacterial growth intolerant to $\mathrm{pH}$ changes (Pirgozliev et al., 2008; Ao et al., 2009), thus providing better intestinal health for the bird to obtain maximum nutrient absorption. Additionally, undissociated organic acids can penetrate the lipid membrane of the bacterial cell and decrease intracellular $\mathrm{pH}$, which leads to death (Ricke, 2003), in addition to stimulating pancreatic secretion and providing better intestinal villus integrity
(Dibner \& Buttin, 2002). However, there are conflicting results regarding the use of acidifiers in poultry and, according to Hernández et al. (2006), these effects depend on the chemical form of the acid, pKa values, bacterial species to be destroyed, animal species and the site of action of acids.

The objective of this study was to evaluate the influence of isolated or associated phytogenic additives and organic acids on the nutrient metabolizability of the diet in the early growth stages, as well as to evaluate the performance and carcass characteristics of broilers.

\section{Material and Methods}

All procedures used in this experiment were approved by the Animal Experimentation Ethics Committee (process no. 183/2008-CEEA) Faculdade de Medicina Veterinária e Zootecnia of UNESP - Campus Botucatu.

Two experiments were conducted with Cobb broilers. The first experiment had two metabolism trials with broilers, in the Faculdade de Medicina Veterinária e Zootecnia of UNESP - Universidade Estadual Paulista, Campus Botucatu at the Poultry Nutrition Laboratory. The second experiment evaluated performance and carcass characteristics in an integrated poultry farm, located in Ipeúna - São Paulo, 
Brazil, and broilers were slaughtered in the experimental slaughterhouse of the Faculdade de Medicina Veterinária e Zootecnia of UNESP - Universidade Estadual Paulista, Campus Botucatu. The experimental design in both experiments was completely randomized in a factorial arrangement with an additional treatment $(2 \times 2+1)$. The diets were formulated with and without phytogenic additives $(\mathrm{PA}) \times$ with and without organic acids $(\mathrm{OA})+$ control diet with antibiotic performance enhancer and anticoccidial drugs, totaling five treatments. The phytogenic additives (Imunostart $^{\circledR}+$ Enterocox $^{\circledR}$ - Phytosynthese) comprised turmeric extracts, citrus extract and grape seed extract + Chinese cinnamon essential oil, Chile Boldo leaves and fenugreek seeds. The organic acid mix (Premium Sal-Ácido $8^{\circledR}$ - Nutriacid) comprised $30.0 \%$ of lactic acid, $25.5 \%$ of benzoic acid, $7 \%$ of formic acid, $8 \%$ of citric acid and $6.5 \%$ of acetic acid. The antibiotic performance enhancer (APE) was composed of avilamycin at 20\%, 10 ppm (Surmax
$200^{\circledR}$, Elanco) plus sodium monensin at $40 \%, 250 \mathrm{~g} /$ ton (Monenpac $\mathrm{MC} 400^{\circledR}$ ).

The diets of both experiments were formulated based on corn and soybean meal and the feed composition and nutritional requirements were obtained from the recommendations by Rostagno et al. (2005) (Table 1). The additives tested in this study were included in the diets as a substitution of inert.

The first experiment included 125 one-day old broiler chicks for two metabolism trials, housed in controlled metabolic cages, provided with front feeder, nipple drinker and excreta-collection trays. The chicks were vaccinated at the hatchery against Marek's disease and Gumboro disease and maintained within a comfort temperature range during the entire experimental design and execution period. Five treatments and five replicates of five birds per experimental unit were conducted in the first test, totaling 125 broilers.

Table 1 - Nutritional and centesimal composition of the experimental diets

\begin{tabular}{|c|c|c|c|c|c|c|c|c|}
\hline \multirow{2}{*}{$\begin{array}{l}\text { Ingredients } \\
\text { (g/kg of natural matter) }\end{array}$} & \multicolumn{2}{|c|}{ Pre-starter } & \multicolumn{2}{|c|}{ Starter } & \multicolumn{2}{|c|}{ Growth } & \multicolumn{2}{|c|}{ Finishing } \\
\hline & $\mathrm{CD} / \mathrm{APE} / \mathrm{PA}$ & $\mathrm{OA} / \mathrm{PAAO}^{1}$ & $\mathrm{CD} / \mathrm{APE} / \mathrm{PA}$ & OA/PAAO & $\mathrm{CD} / \mathrm{APE} / \mathrm{PA}$ & OA/PAAO & $\mathrm{CD} / \mathrm{APE} / \mathrm{PA}$ & $\mathrm{OA} / \mathrm{PAAO}$ \\
\hline Corn & 559.6 & 556.7 & 569.3 & 566.2 & 598.6 & 597.3 & 643.2 & 642.4 \\
\hline Soybean meal (45\%) & 373.2 & 373.5 & 355.5 & 356.0 & 319.5 & 319.7 & 278.7 & 278.8 \\
\hline Dicalcium phosphate & 19.5 & 19.5 & 18.4 & 18.4 & 17.0 & 17.0 & 15.4 & 15.4 \\
\hline Soybean oil & 22.3 & 22.8 & 34.7 & 35.3 & 44.2 & 44.3 & 42.9 & 43.0 \\
\hline DL-methionine $(99.0 \%)$ & 2.3 & 2.4 & 1.7 & 1.7 & 1.6 & 1.6 & 1.6 & 1.6 \\
\hline Choline chloride $(60 \%)$ & 0.6 & 0.6 & 0.5 & 0.5 & 0.5 & 0.5 & 0.4 & 0.4 \\
\hline Sodium bicarbonate & 0.8 & 0.3 & 0.5 & 0.0 & 0.1 & 0.0 & 0.0 & 0.0 \\
\hline Salt & 4.6 & 4.6 & 4.7 & 4.7 & 4.7 & 4.5 & 4.6 & 4.4 \\
\hline Inert & 1.0 & 4.5 & 1.5 & 5.0 & 1.5 & 3.5 & 0.8 & 2.0 \\
\hline Vitamin supplement ${ }^{2}$ & 1.0 & 1.0 & 1.0 & 1.0 & 0.8 & 0.8 & 0.5 & 0.5 \\
\hline Mineral supplement ${ }^{3}$ & 0.5 & 0.5 & 0.5 & 0.5 & 0.5 & 0.5 & 0.5 & 0.5 \\
\hline Crude fiber ${ }^{4}$ & 30.2 & 31.2 & 29.6 & 30.6 & 28.2 & 28.8 & 26.5 & 26.9 \\
\hline Digestible lysine $^{4}$ & 13.6 & 13.6 & 11.9 & 11.9 & 11.0 & 11.0 & 10.5 & 10.5 \\
\hline Digestible methionine $^{4}$ & 5.4 & 5.4 & 4.6 & 4.6 & 4.4 & 4.4 & 4.2 & 4.2 \\
\hline Digestible methionine + cystine ${ }^{4}$ & 8.4 & 8.4 & 7.5 & 7.5 & 7.1 & 7.1 & 6.8 & 6.8 \\
\hline Digestible threonine $^{4}$ & 8.8 & 8.8 & 7.7 & 7.7 & 7.1 & 7.1 & 6.8 & 6.8 \\
\hline Digestible tryptophan ${ }^{4}$ & 2.4 & 2.4 & 2.3 & 2.3 & 2.1 & 2.1 & 1.9 & 1.9 \\
\hline Linoleic acid ${ }^{4}$ & 24.8 & 24.9 & 31.5 & 1.7 & 36.9 & 36.9 & 36.7 & 36.8 \\
\hline Calcium $^{4}$ & 9.4 & 9.0 & 9.0 & 8.6 & 8.4 & 8.1 & 7.7 & 7.6 \\
\hline Available phosphorous ${ }^{4}$ & 4.7 & 4.7 & 4.5 & 4.5 & 4.2 & 4.2 & 3.9 & 3.9 \\
\hline Potassium $^{4}$ & 8.4 & 8.4 & 8.1 & 8.1 & 7.5 & 7.5 & 6.9 & 6.9 \\
\hline Sodium ${ }^{4}$ & 2.2 & 2.0 & 2.2 & 2.0 & 2.1 & 2.0 & 2.0 & 1.9 \\
\hline Chloride $^{4}$ & 3.2 & 3.2 & 3.2 & 3.2 & 3.2 & 3.1 & 3.1 & 3.1 \\
\hline
\end{tabular}

\footnotetext{
${ }^{1} \mathrm{CD}$ - control diet; APE - antibiotic performance enhancer; PA - phytogenic additives; OA - organic acids; PAAO - phytogenic additives + organic acids. Considering nutritional levels of the organic acids (Premium Acid-Salt 8: IN - 1,200 kcal $/ \mathrm{kg} ; \mathrm{FC}-11 \%$ available; $\mathrm{Na}-4.5 \%$ ).

${ }^{2}$ MC-MIX Starter Broiler $1 \mathrm{~kg}\left(\right.$ Mcassab $\left.^{\circledR}\right)$ guaranteed/kg feed levels for pre-starter and initial stages: vit. A - 11,000 IU; vit. D3 - 2,000 IU; vit. E - $16 \mathrm{mg}$; folic acid - $0.4 \mathrm{mg}$; calcium pantothenate - $10 \mathrm{mg}$; biotin - $0.06 \mathrm{mg}$; niacin - $35 \mathrm{mg}$; pyridoxine - $2 \mathrm{mg}$; riboflavin - $4.5 \mathrm{mg}$; thiamine - $1.2 \mathrm{mg}$; vit. B12 - $16 \mathrm{mcg}$; vit. K3 - $1.5 \mathrm{mg}$; Se - $0.25 \mathrm{mg}$; antioxidant - $30 \mathrm{mg}$.

MC-MIX Starter Broiler $1 \mathrm{~kg}$ (Mcassab ${ }^{\circledR}$ ) guaranteed/kg feed levels growth stage: vit. A - 8,800 IU; vit. D3 - 1,600 IU; vit. E - $12.8 \mathrm{mg}$; folic acid - $0.32 \mathrm{mg}$; calcium pantothenate - 8 mg; biotin - $0.048 \mathrm{mg}$; niacin - $28 \mathrm{mg}$; pyridoxine - $1.6 \mathrm{mg}$; riboflavin - $3.6 \mathrm{mg}$; thiamine - $0.96 \mathrm{mg}$; vit. B12, $12.8 \mathrm{mcg}$; vit. K3 - $1.2 \mathrm{mg}$; Se - $0.2 \mathrm{mg}$; antioxidant - $24 \mathrm{mg}$.

MC-MIX Broilers $0.5 \mathrm{~kg}\left(\right.$ (Mcassab $\left.^{\mathbb{R}}\right)$ guaranteed/kg feed levels: vit. A - 3,000 IU; vit. D3 - $500 \mathrm{IU}$; vit. E - 5 mg; calcium pantothenate - 4 mg; biotin - 0.015 mg; niacin - 5 mg; pyridoxine - $0.4 \mathrm{mg}$; riboflavin - $1 \mathrm{mg}$; thiamine - $0.3 \mathrm{mg}$; vit. B12 - $3 \mathrm{mcg}$; vit. K3 - $0.5 \mathrm{mg}$; Se, $0.2 \mathrm{mg}$; antioxidant, $15 \mathrm{mg}$.

${ }^{3}$ MC-MIX Mineral Broilers $0.5 \mathrm{~kg}\left(\right.$ Mcassab $\left.^{\circledR}\right)$ guaranteed $/ \mathrm{kg}$ feed levels: $\mathrm{Cu}-9 \mathrm{mg}$; Zn - $60 \mathrm{mg}$; I $1 \mathrm{mg} ; \mathrm{Fe}-30 \mathrm{mg} ; \mathrm{Mn}-60 \mathrm{mg}$.

${ }^{4} \mathrm{~g} / \mathrm{kg}$ of natural matter.
} 
For the second metabolism trial, three chickens from each experimental unit were used according to space, feeder and cage area suitability, totaling 75 broilers.

The tests were performed in two periods, 11 to 21 and 25 to 35 days of age, with five days of adaptation to the experimental diets and five days for total excreta collection, using the method of total excreta collection.

The excreta were collected twice a day ( $8 \mathrm{~h}$ and $17 \mathrm{~h})$, packed in labeled plastic bags and stored in a freezer $\left(-10^{\circ} \mathrm{C}\right)$. At the end of each experimental period, the amount of feed consumed and the total amount of excreta produced were determined, they were thawed, weighed, homogenized and a sample was removed and weighed for bromatological analysis.

With the excreta and feed, the dry matter, total nitrogen and ether extract were determined according to the methodology by Silva \& Queiroz (2002) and gross energy using bomb calorimeter (IKA ${ }^{\circledR}$ - Werke). The gross energy metabolizability coefficients (GEMC) were determined by calculating the ratio of GEMC and gross energy (GE) in percentage, metabolizability coefficients of dry matter (DMMC), nitrogen (NMC) and ether extract (EEMC). The values of apparent metabolizable energy (AME) and nitrogen-corrected apparent metabolizable energy (AMEn) were calculated according to Matterson et al. (1965).

In the second experiment, 2520 one-day old male chicks were used, with an average initial weight of $50 \pm 1 \mathrm{~g}$, in a completely randomized $2 \times 2+1$ factorial arrangement with five treatments and eight replicates, totaling 63 birds per experimental unit.

The chicks were vaccinated at the hatchery against Marek's disease and Gumboro disease and housed in $4.5 \mathrm{~m}^{2}$ cages (density of $14 \mathrm{birds} / \mathrm{m}^{2}$ ), equipped with $10 \mathrm{~cm}$ thick wood shavings bed, and fitted with tubular feeders and pendular drinkers. The wood shavings bed used in this experiment was reused from a batch of chickens which received, via drinking water, aqueous solution contaminated with Clostridium perfringens. The drinkers were washed every two days, in order to increase health challenge.

The experimental diets were divided into four phases: pre-starter ( 1 - 10 days $)$, starter $(11-21$ days $)$, growth ( $22-35$ days) and finishing ( $36-42$ days) (Table 1$)$. Water and food were given ad libitum during the entire rearing period and the light program was of 24 hours.

The parameters of body weight (BW), weight gain (WG), feed intake (FI), feed conversion ratio (FCR) and viability (VB) were determined for the periods of 1 to 21 and 1 to 42 days of age and daily mortality was recorded. At the end of the experiment, the production efficiency factor
(PEF) was determined by the following formula: PEF = $(\mathrm{BW} \times \mathrm{VB}) /(\mathrm{FCR} \times$ slaughter age $)$.

At the end of the experiment, four chickens were removed, with an average weight of each experimental unit, and fasted for eight hours. Next, they were sacrificed by stunning followed by exsanguination, plucked and eviscerated for determination of carcass yield, cuts (breast, thigh + drumstick, back and wing) and abdominal fat percentage.

The results obtained in the experiments underwent analysis of variance (ANOVA) of the General Linear Model (GLM) procedure using the statistical program SAS (Statistical Analysis System, version 9.0) and, when significant, the means of the factorial treatment $(2 \times 2)$ were compared by $\mathrm{F}$ tests $(\alpha=0.05)$, and to compare the means of factorial treatments with an additional treatment (APE), Dunnett's test was applied $(\alpha=0.05)$.

\section{Results and Discussion}

There was no interaction between phytogenic additives (PA) and organic acids (OA) for GEMC, DMMC and EEMC in the starter phase (11 to 21 days old) (Table 2). However, PA supplementation improved $(\mathrm{P}<0.05)$ GEMC, DMMC and EEMC, corroborating the results of Hernandéz et al. (2004), who observed improvement for DMMC and EEMC with the inclusion of plant extracts and essential oils in the diet.

The improvement in these variables can be attributed to cinamaldehyde and turmeric, the main active ingredients in cinnamon and curcumin, respectively. Cinamaldehyde stimulates pancreatic and intestinal enzyme secretion (Jamroz et al., 2005) and curcumin increases bile production in the liver and also pancreatic and intestinal lipase (Platel \& Srinivasan, 2004), and consequently the secretion of bile salts. Thus, one can infer that the increase of enzymes and bile salts promoted improved nutrient absorption.

Broilers fed organic acids had higher values $(\mathrm{P}<0.01)$ of GEMC and EEMC than those fed diets without organic acids. These results corroborate the studies of Pirgozliev et al. (2008), who observed AMEn improvement in young broilers fed diets supplemented with fumaric acid and sorbic acid, and also corroborate studies conducted by Ao et al. (2009), in which citric acid increased the metabolizable dry matter and crude protein. However, Hernández et al. (2006) observed no differences in the metabolization of total and ileal dry matter and crude protein in the 16 to 21 day-old period in broilers fed two levels of formic acid. This improvement in metabolizable energy may be due to the AME acids available in the mixture, improving the 
intestinal villus integrity and increasing the absorption of lipids.

There was interaction $(\mathrm{P}<0.01)$ between $\mathrm{PA}$ and $\mathrm{OA}$ for nitrogen metabolizability coefficient (NMC) (Table 2). The inclusion of PA in the diets with and without OA improved the NMC of the broilers; however, the combination of additives resulted in lower metabolization, which, in this case, shows no additive effect for NMC, since OA did not improve metabolizability when compared with the control diet. The present study contradicts the results obtained by Muhl \& Liebert (2007), who found no differences in protein metabolizability and nitrogen balance of broiler chickens fed commercial PA.

The results presented in this study partially contradict those obtained by Basmacioğlu Malayoğlu et al. (2010), who found no differences in the metabolizability of dry matter and ether extract in broilers fed diets containing oregano essential oil; the same observed for lipase and amylase activity. Cross et al. (2007) also observed no differences in DMMC and GEMC when assessing the metabolizability influence of different plant extracts. However, the mixture of active principles in the PA of the present study may have shown increased enzyme activity, which promoted improved nutrient metabolizability.

Comparing the alternative treatments with APE (Table 2), the broilers fed the diet without additive supplementations showed lower values $(\mathrm{P}<0.05)$ for all the variables analyzed, in comparison with those that received APE, except for NMC, which showed no differences. The use of PA reduced $(\mathrm{P}<0.01)$ the GEMC and EEMC values, but increased nitrogen metabolizability. For the broilers fed diets containing $\mathrm{OA}$, this additive did not improve the GEMC values, which showed lower values, in comparison with the broilers that received APE. The association of PA and OA did not differ statistically for the variables studied in relation to the positive control, demonstrating that the effects of stimulating pancreatic and intestinal enzyme secretion and improved villus integrity promoted by the additives provided similar results to the action of antibiotics to reduce bacterial pathogens and lesions in the villi.

There was interaction $(\mathrm{P}<0.05)$ between $\mathrm{PA}$ and $\mathrm{OA}$ for all the variables evaluated in the growth phase (25 to 35 days) (Table 2). The broilers fed PA had the highest GEMC, DMMC, NMC and EEMC values compared with

Table 2 - Nutrient metabolization in diets containing phytogenic additives (PA) and organic acids (OA) for broilers at 11 to 21 and 25 to 35 days of age

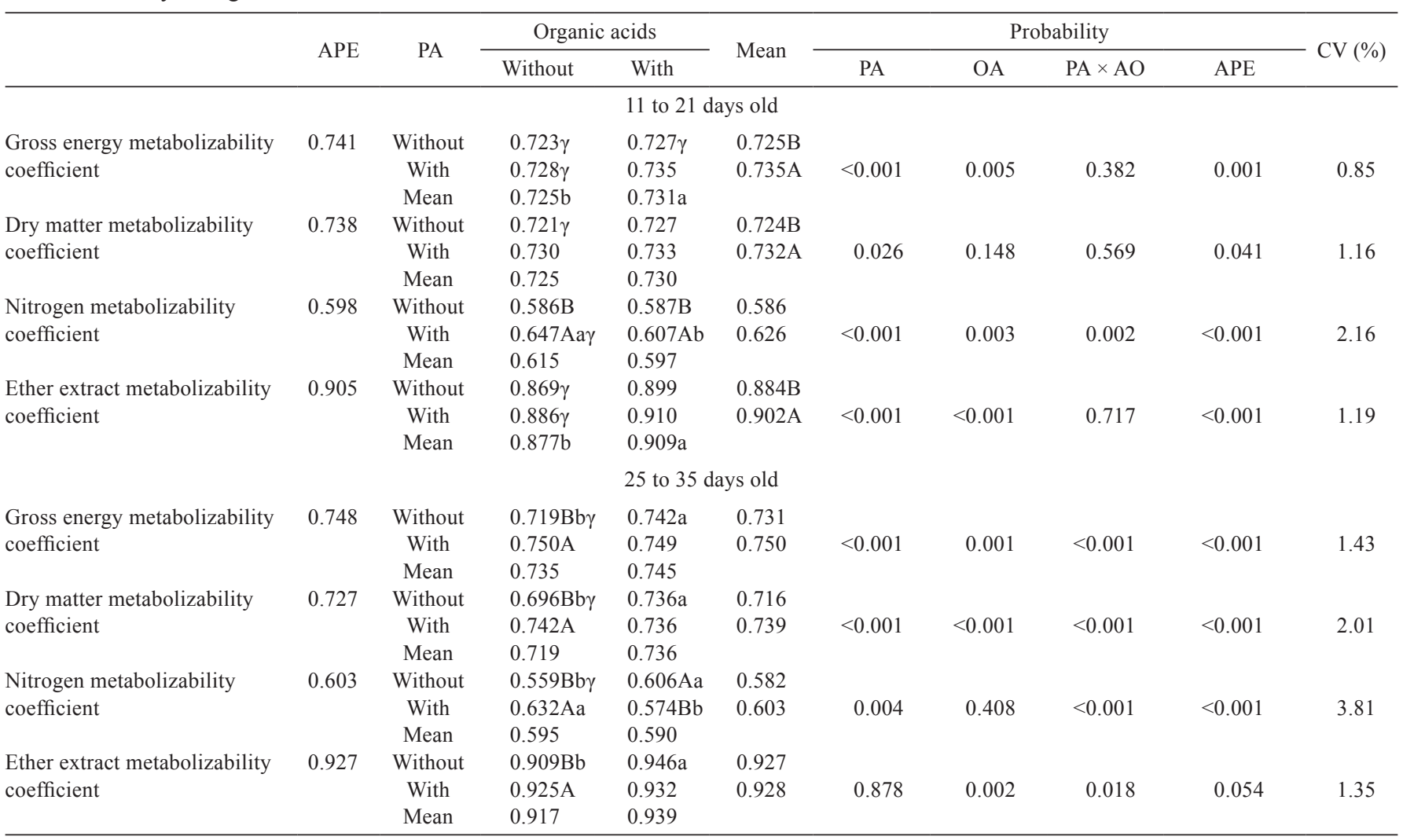

Values expressed in $\mathrm{g} / \mathrm{g}$.

APE - antibiotic performance enhancer; CV - coefficient of variation.

Means followed by uppercase letters in the column and lowercase letters in the row differ by the F test $(\alpha=0.05)$. $\gamma-$ differs with the antibiotic performance enhancer (APE) by Dunnett's test $(\alpha=0.05)$. 
the broilers that were not fed the additives. However, the association of PA and OA caused lower NMC in the broilers than those fed diets containing only organic acids. Similar results were found by Hernandéz et al. (2004) and García et al. (2007), who observed improved ileal digestibility of dry matter and crude protein of the birds fed phytogenic additives.

However, studies have shown that the use of plant extracts and essential oils may not improve AME values and protein and dry matter metabolizability (Cross et al., 2007; Muhl \& Liebert, 2007; Barreto et al., 2008; Rizzo et al., 2010). According to Lee et al. (2003) and Rizzo et al. (2010), diets with highly digestible ingredients can mask the improvement these additives can provide to the metabolizability of nutrients, which is not observed in this study, even when using vegetal-derived feeds with high biological value.

The broilers fed diets supplemented with organic acids and not supplemented with PA had higher GEMC, DMMC, NMC and EEMC values $(\mathrm{P}<0.05)$, in comparison with those fed diets without the additives, partially corroborating Ao et al. (2009), who found that citric acid increased dry matter and crude protein metabolizability. However, when the birds were fed a combination of phytogenic additives and organic acids, they had lower NMC in comparison with those without organic acids supplementation and with PA supplementation.

The results from this study partially contradict those reported by Hernández et al. (2006), who, studying the inclusion level of formic acid in broiler diets, found no metabolic improvement in the birds fed acid, in comparison with the birds fed avilamycin or a basal diet.

When compared with APE, in which the use of additivefree diets resulted in lower GEMC, DMMC and NMC, the additives tested showed no differences for the metabolic coefficients, confirming García et al. (2007), who, studying the supplementation of formic acid and plant extracts, did not observe metabolic differences in comparison with the birds supplemented with avilamycin, and also Hernández et al. (2006), who did not observe metabolic differences in the broilers that received organic acid or avilamycin. One of these causes may be the low sanitary challenge imposed to these birds and the stimulation of pancreatic and intestinal enzymes in birds fed PA and organic acids.

The possible causes of improved nutrient metabolizability in the diets of broilers fed phytogenics are associated with the stimulation and production of digestive enzymes such as lipase, amylase, trypsin, chymotrypsin and maltase found by some researchers (Lee et al., 2003; Jamroz et al., 2005; Jang et al., 2007; Basmacioğlu Malayoğlu et al., 2010), in addition to the antimicrobial activity and decreased $\mathrm{pH}$ by $\mathrm{PA}$ and organic acids alone or combined. In a study by Jamroz et al. (2006), the authors found decreased colonization of pathogens due to increased mucus production and increased thickness of the stomach and jejunum in the birds fed phytogenic additives, which may have contributed to the improved nutrient metabolizability.

Considering the coefficients of nutrient metabolizability in the present study, one can infer that the phytogenics improved the health of chickens due to the higher production of pancreatic enzymes, thus improving the gastrointestinal tract and consequent modulation of the microbiota, which was observed from the start of supplementation in the starter phase, the same way that the acidifiers helped to improve metabolism in the growth phase, and this improvement in the metabolism coefficients with the use of organic acids may have been influenced by greater intestinal contents, with the need for decreased $\mathrm{pH}$ in the different segments of the intestine.

Thus, phytogenics and acidifiers can act as alternatives to APE, as they help bring about better nutrient absorption, which is mostly intended for muscle growth, without major tissue renewal consumption.

There was no significant interaction between phytogenic additives and organic acids at 21 days of age (Table 3). Moreover, these additives did not influence the performance improvement of the broilers, in comparison with those that received the control diet. When comparing the FI of birds fed diets with or without organic acids, it is observed that, on average, the birds fed diets containing organic acids showed a higher FI.

The broilers fed diets supplemented with APE showed better results for all performance variables, except for FI and viability, in which there was no difference between treatments. This result is expected, since in a challenged environment, the birds fed antibiotics showed better performance than those fed alternative additives.

In this study, the results observed for BW, WG and FCR at 21 days contrast with the studies performed with other PA (Fukayama et al., 2005; Toledo et al., 2007; Kumar et al., 2010; Rizzo et al., 2010), with no differences for these variables between the broilers that received alternative additives and antibiotics in the diet. Similarly, studies with organic acids also showed no performance difference, in comparison with the negative control and/or the birds fed antibiotics (Gunal et al., 2006; Abdel-Fattah et al., 2008; Vieira et al., 2008; Faria et al., 2009). However, most of the studies that used these additives in broilers were conducted in low health challenge environments.

At 42 days of age, there was no interaction between phytogenic additives and organic acids (Table 4) for the 
performance characteristics studied. The broilers fed diets containing PA showed better FCR than the birds fed nonsupplemented diets, and the birds fed diets containing organic acids showed higher BW and WG than those fed without organic acids supplementation. Although there are no performance differences between the treatments, the association of phytogenic additves and organic acids can be used in order to improve performance. Additive and/or synergistic effect was observed with the combinations of probiotics and acidifiers (Khosravi et al., 2010), sanguinarine and organic acids (Vieira et al., 2008), essential oils and enzymes (Basmacioğlu Malayoğlu et al., 2010), acidifiers and enzymes (Smulikowska et al., 2010) and phytogenics and probiotics, improving the immune system of the birds (Li et al., 2009).

The broilers that were fed diets supplemented with APE showed the best performance results, showing that the alternative additives were not totally effective to the challenge posed.

In the present experiment, the birds fed alternative additives during the 1 to 42 day-old period showed improved performance, in comparison with the diets without supplementation. The results obtained are similar to those that were fed phytogenics, when compared with the diets without any additive supplementation, compiled by Windisch et al. (2008) with birds reared in the different

Table 3 - Performance of broiler chicks fed diets supplemented with phytogenic additives (PA) and organic acids (OA) at 21 days of age

\begin{tabular}{|c|c|c|c|c|c|c|c|c|c|c|}
\hline & \multirow{2}{*}{$\mathrm{APE}$} & \multirow{2}{*}{$\mathrm{PA}$} & \multicolumn{2}{|c|}{ Organic acids } & \multirow{2}{*}{ Mean } & \multicolumn{4}{|c|}{ Probability } & \multirow{2}{*}{$\mathrm{CV}(\%)$} \\
\hline & & & Without & With & & PA & $\mathrm{OA}$ & $\mathrm{PA} \times \mathrm{AO}$ & APE & \\
\hline \multirow[t]{3}{*}{ Body weight (g) } & 969 & Without & $881 \gamma$ & $897 \gamma$ & 889 & & & & & \\
\hline & & With & $896 \gamma$ & $903 \gamma$ & 899 & 0.236 & 0.192 & 0.569 & $<0.001$ & 2.60 \\
\hline & & Mean & 888 & 899 & & & & & & \\
\hline \multirow[t]{3}{*}{ Weight gain $(\mathrm{g})$} & 919 & Without & $831 \gamma$ & $848 \gamma$ & 849 & & & & & \\
\hline & & With & $846 \gamma$ & $853 \gamma$ & 839 & 0.236 & 0.182 & 0.542 & $<0.001$ & 2.76 \\
\hline & & Mean & 838 & 850 & & & & & & \\
\hline \multirow[t]{3}{*}{ Feed intake $(\mathrm{g})$} & 1365 & Without & 1315 & 1353 & 1334 & & & & & \\
\hline & & With & 1330 & 1355 & 1342 & 0.553 & 0.037 & 0.641 & 0.113 & 3.07 \\
\hline & & Mean & $1322 b$ & $1354 a$ & & & & & & \\
\hline \multirow[t]{3}{*}{ Feed conversion ratio $(\mathrm{g}: \mathrm{g})$} & 1.49 & Without & $1.61 \gamma$ & $1.62 \gamma$ & 1.61 & & & & & \\
\hline & & With & $1.52 \gamma$ & $1.60 \gamma$ & 1.59 & 0.285 & 0.377 & 0.899 & $<0.001$ & 3.49 \\
\hline & & Mean & 1.59 & 1.61 & & & & & & \\
\hline \multirow[t]{3}{*}{ Viability (\%) } & 98.41 & Without & 97.35 & 95.83 & 96.59 & & & & & \\
\hline & & With & 97.63 & 97.73 & 97.68 & 0.481 & 0.646 & 0.598 & 0.749 & 3.99 \\
\hline & & Mean & 97.49 & 96.78 & & & & & & \\
\hline
\end{tabular}

APE - antibiotic performance enhancer; CV - coefficient of variation.

Means followed by uppercase letters in the column and lowercase letters in the row differ by the F test $(\alpha=0.05)$. $\gamma$ - differs with the antibiotic performance enhancer (APE) by Dunnett's test $(\alpha=0.05)$.

Table 4 - Performance of broilers fed diets supplemented with phytogenic additives and organic acids at 42 days of age

\begin{tabular}{|c|c|c|c|c|c|c|c|c|c|c|}
\hline & \multirow{2}{*}{ APE } & \multirow{2}{*}{ PA } & \multicolumn{2}{|c|}{ Organic acids } & \multirow{2}{*}{ Mean } & \multicolumn{4}{|c|}{ Probability } & \multirow{2}{*}{ CV $(\%)$} \\
\hline & & & Without & With & & PA & $\mathrm{OA}$ & $\mathrm{PA} \times \mathrm{AO}$ & $\mathrm{APE}$ & \\
\hline \multirow[t]{3}{*}{ Body weight (g) } & 2982 & Without & $2721 \gamma$ & $2789 \gamma$ & 2755 & & & & & \\
\hline & & With & $2763 \gamma$ & $2825 \gamma$ & 2794 & 0.061 & 0.003 & 0.891 & $<0.001$ & 1.87 \\
\hline & & Mean & $2742 b$ & $2807 \mathrm{a}$ & & & & & & \\
\hline \multirow[t]{3}{*}{ Weight gain (g) } & 2932 & Without & $2671 \gamma$ & $2740 \gamma$ & 2705 & & & & & \\
\hline & & With & $2713 \gamma$ & $2776 \gamma$ & 2744 & 0.062 & 0.003 & 0.878 & $<0.001$ & 1.91 \\
\hline & & Mean & $2692 b$ & $2757 \mathrm{a}$ & & & & & & \\
\hline \multirow[t]{3}{*}{ Feed intake (g) } & 5087 & Without & 4985 & 5029 & 5007 & & & & & \\
\hline & & With & $4955 \gamma$ & 5004 & 4980 & 0.404 & 0.159 & 0.937 & 0.056 & 1.76 \\
\hline & & Mean & 4970 & 5017 & & & & & & \\
\hline \multirow[t]{3}{*}{ Feed conversion ratio (g:g) } & 1.76 & Without & $1.89 \gamma$ & $1.87 \gamma$ & $1.88 \mathrm{~A}$ & & & & & \\
\hline & & With & $1.86 \gamma$ & $1.84 \gamma$ & $1.85 \mathrm{~B}$ & 0.032 & 0.298 & 0.833 & $<0.001$ & 2.15 \\
\hline & & Mean & 1.87 & 1.86 & & & & & & \\
\hline \multirow[t]{3}{*}{ Viability (\%) } & 95.01 & Without & 95.87 & 92.06 & 93.96 & & & & & \\
\hline & & With & 93.33 & 93.20 & 93.26 & 0.672 & 0.240 & 0.273 & 0.412 & 4.55 \\
\hline & & Mean & 94.60 & 92.63 & & & & & & \\
\hline \multirow[t]{3}{*}{ Production efficiency factor } & 384 & Without & $329 \gamma$ & $327 \gamma$ & 328 & & & & & \\
\hline & & With & $331 \gamma$ & $341 \gamma$ & 335 & 0.351 & 0.634 & 0.442 & $<0.001$ & 6.23 \\
\hline & & Mean & 329 & 333 & & & & & & \\
\hline
\end{tabular}

APE - antibiotic performance enhancer; CV - coefficient of variation.

Means followed by uppercase letters in the column and lowercase letters in the row differ by the F test $(\alpha=0.05)$. $\gamma$ - differs with the antibiotic performance enhancer (APE) by Dunnett's test $(\alpha=0.05)$. 
lodgings and challenges, and higher than the data compiled by Fascina (2011) for phytogenic additives and organic acids, for broilers raised in low-challenge environments.

The highest yield in poultry excreta with advancing age, poor bed quality and confirmed clinical signs of necrotic enteritis with low pathogenicity in the birds of all experimental units provided considerable health challenge to the broilers in this study.

No differences are seen in the literature for alternative additives, antibiotics and diets without additive supplementations in broilers, as they are generally raised in low health challenge environments (Hernández et al., 2004; Fukayama et al., 2005; Muhl \& Liebert, 2007; Toledo et al., 2007; Rizzo et al., 2010), demonstrating that in the present study it was possible to provide real health challenges, which poultry industries constantly encounter in largescale poultry production.

The use of PA showed higher carcass yield in broilers that were fed this additive $(\mathrm{P}<0.01)$ (Table 5), contradicting Muhl \& Liebert (2007), who found no differences in the carcass yield of broilers fed plant extracts. This result demonstrates that the broilers that received PA had better nutrient absorption, favoring deposition in the muscle tissue, a fact observed in the metabolism trial, considering that the broilers in this treatment had higher metabolism coefficients of nitrogen, fat and gross energy. The broilers fed diets containing organic acids showed higher wing yield $(\mathrm{P}<0.05)$ and lower thigh + drumstick yield $(\mathrm{P}<0.05)$, in comparison with the birds fed without organic acids supplementation (Table 5).
There was interaction $(\mathrm{P}<0.01)$ between phytogenic additives and organic acids for the breast and back yields (Table 5). The broilers fed diets containing only PA had higher breast yield and lower back yield than those that received no feed additives, and those that were fed diets supplemented only with organic acids had lower breast yield and higher back yield.

When the alternative treatments were compared with broilers fed diets containing APE and anticoccidial, there was no difference in back yield and abdominal fat percentage. For carcass yield, the birds fed APE had higher $(\mathrm{P}<0.01)$ yields than those fed alternative additives or without supplementation, which was expected for this characteristic, since the broilers in this treatment had the highest body weight at the end of the rearing period. The higher carcass yield enables to infer that the antibiotic promoted reduced sanitary challenges for these broilers, which is reflected in the higher performance and yield. This result corroborates the results of Samanta et al. (2008) and Chowdhury et al. (2009), who evaluated the use of acidifiers in broiler diets.

For breast yield, the alternative additives showed performance similar to the positive control birds. However, the birds fed without supplementation had lower $(\mathrm{P}<0.05)$ breast yield, in comparison with the positive control. The percentage of abdominal fat of birds fed the additives was not affected, corroborating other studies that found no differences for this characteristic (Carrijo et al., 2005; Fukayama et al., 2005; Jamroz et al., 2005; Rizzo et al. 2010).

Table 5 - Carcass characteristics of broilers fed diets supplemented with phytogenic additives (PA) and organic acids (OA) at 42 days of age

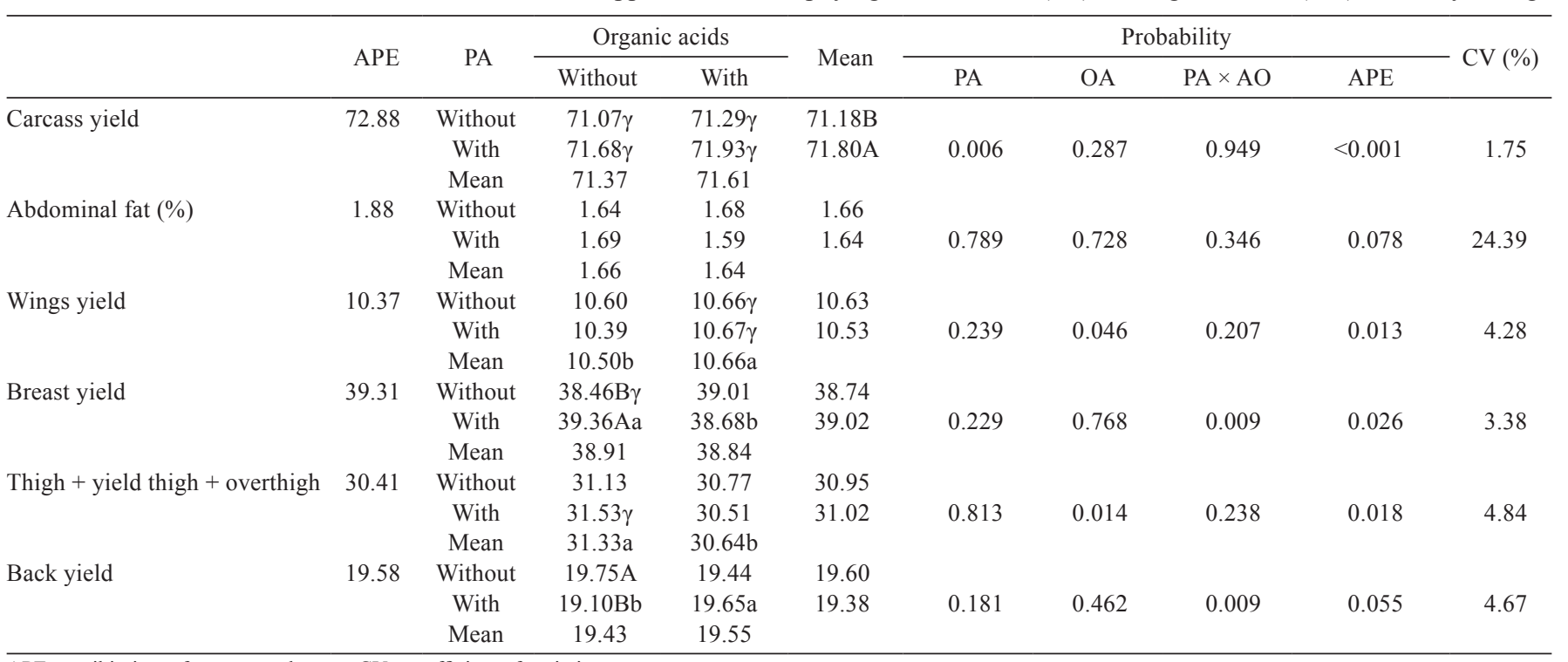

APE - antibiotic performance enhancer; CV - coefficient of variation.

Means followed by uppercase letters in the column and lowercase letters in the row differ by the F test $(\alpha=0.05)$. $\gamma$ - differs with the antibiotic performance enhancer (APE) by Dunnett's test $(\alpha=0.05)$.

${ }^{1}$ Yield, g/100 g. 


\section{Conclusions}

Phytogenic additives and organic acids improve nutrient metabolizability in broilers at the initial growth stages. The use of organic acids, alone or associated with phytogenic additives in broiler diets, is an alternative, given the ban on antibiotic growth promoters.

\section{Acknowledgements}

The authors are grateful to FAPESP for the doctorate and scientific initiation grants to the authors of this study (Process No. 2008/55428-7 and 2009/52647-2).

\section{References}

ABDEL-FATTAH, S.A.; EL-SANHOURY, M.H.; EL-MEDNAY, N.M. et al. Thyroid activity some blood constituents, organs morphology and performance of broiler chicks fed supplemental organic acids. International Journal of Poultry Science, v.7, p.215-222, 2008

AO, T.; CANTOR, A.H.; PESATORE, A.J. et al. Effect of enzyme supplementation and acidification of diets on nutrient digestibility and growth performance of broiler chicks. Poultry Science, v.88, p.111-117, 2009.

BARRETO, M.S.R.; MENTEN, J.F.M.; RACANICCI, A.M.C. et al. Plant extracts used as growth promoters in broilers. Revista Brasileira de Ciência Avícola, v.10, p.109-114, 2008.

BASMACIOĞLU MALAYOĞLU, H.; BAYSAL, S.; MISIRLIOGLU, Z. et al. Effects of oregano essential oil with or without feed enzymes on growth performance, digestive enzyme, nutrient digestibility, lipid metabolism and immune response of broilers fed on wheat-soybean meal diets. British Poultry Science, v.52, p.67-80, 2010.

CARRIJO, A.S.; MADEIRA, L.A.; SARTORI, J.R. et al. Alho em pó na alimentação alternativa de frangos de corte. Pesquisa Agropecuária Brasileira, v.40, p.673-679, 2005.

CHOWDHURY, R.; ISLAM, K.M.S.; KHAN, M.J. et al. Effect of citric acid, avilamycin, and their combination on the performance, tibia ash, and immune status of broilers. Poultry Science, v.88, p.1616-1622, 2009.

CROSS, D.E.; McDEVITT, R.M.; HILLMAN, K. et al. The effect of herb and their associated essential oils on performance, dietary digestibility and gut microflora in chickens form 7 to 28 days of age. British Poultry Science, v.48, p.496-506, 2007.

DIBNER, J.J.; BUTTIN, P. Use of organic acids as a model to study the impact of gut microflora on nutrition and metabolism. The Journal of Applied Poultry Research, v.11, p.453-463, 2002.

FARIA, D.E.; HENRIQUE, A.P.F.; FRANZOLIN NETO, R. et al. Alternativas ao uso de antibióticos como promotores de crescimento para frangos de corte: 2. Ácidos orgânicos e probióticos. Ciência Animal Brasileira, v.10, p.29-39, 2009.

FASCINA, V.B. Aditivos fitogênicos e ácidos orgânicos em dietas para frangos de corte. 2011. 157f. Tese (Doutorado em Zootecnia) - Universidade Estadual Paulista, Botucatu.

FUKAYAMA, E.H.; BERTECHINI, A.G.; GERALDO, A. Et al. Extrato de orégano como aditivo em rações para frangos de corte. Revista Brasileira de Zootecnia, v.34, p.2316-2326, 2005.

GARCÍA, V.; CATALÁ-GREGORI, P.; HERNÁNDEZ, F. et al. Effect of formic acid and plant extracts on growth, nutrient digestibility, intestine mucosa morphology, and meat yield of broilers. The Journal of Applied Poultry Research, v.16, p.555-562, 2007.
GUNAL, M.; YAYLI, G.; KAYA, O. et al. The effects of antibiotic growth promoter, probiotic or organic acids supplementation on performance, intestinal microflora and tissue of broilers. International Journal of Poultry Science, v.5, p.149-155, 2006.

HERNANDÉZ, F.; MADRID, J.; GARCÍA, V. et al. Influence of two plant extracts on broilers performance, digestibility, and digestive organ size. Poultry Science, v.83, p.169-174, 2004.

HERNÁNDEZ, F.; GARCÍA, V.; MADRID, J. et al. Effect of formic acid on performance, digestibility, intestinal histomorphology and plasma metabolite levels of broiler chickens. British Poultry Science, v.47, p.50-56, 2006.

JAMROZ, D.; WILICZKIEWICZ, A.; WERTELECKI, T. et al. Use of active substances of plant origin in chicken diets based on maize and domestic grains. British Poultry Science, v.46, p.485-493, 2005.

JAMROZ, D.; WERTELECKI, T.; HOUSZKA, M. et al. Influence of diet type on the inclusion of plant origin active substances on morphological and histochemical characteristics of the stomach and jejunum walls in chicken. Journal of Animal Physiology and Animal Nutrition, v.90, p.255-268, 2006.

JANG, I.S.; KO, Y.H.; KANG, S.Y. et al. Effect of a commercial essential oil on growth performance, digestive enzyme activity and intestinal microflora population in broiler chickens. Animal Feed Science and Technology, v.134, p.304-315, 2007.

KHOSRAVI, A.; BOLDAJI, F.; DASTAR, B. et al. Immune response and performance of broiler chicks fed protexin na propionic acid. International Journal of Poultry Science, v.9, p.188-191, 2010.

KUMAR, S.; SHARADAMMA, K.C.; RADHAKRISHNA, P.M. Effects of a garlic active basead growth promoter on growth performance and specific pathogenic intestinal microbial counts of broiler chicks. International Journal of Poultry Science, v.9, p.244-246, 2010.

LEE, K.W.; KAPPERT, H.J.; FREHNER, M. et al. Effects of dietary essential oil components on growth performance, digestive enzymes and lipid metabolism in female broiler chickens. British Poultry Science, v.44, p.450-457, 2003.

LI, S.P.; ZHAO, X.J.; WANG, J.Y. Synergy of Astragalus polysaccharides and probiotics (Lactobacillus and Bacillus cereus) on immunity and intestinal microbiota in chicks. Poultry Science, v.88, p.519-525, 2009.

MATTERSON, L.D.; POTTER, L.M.; STUTZ, M.W. et al. The metabolizable energy of feeds ingredients for chikens. Connecticut: Uniconn Press, 1965. 11p.

MUHL, A.; LIEBERT, F. Growth nutrient utilization and threonine requirement of growing chicken fed threonine limiting diets with commercial blends of phytogenic feed additives. The Journal of Poultry Science, v.44, p.297-304, 2007.

PIRGOZLIEV, V.; MUROHY, T.C.; OWENS, B. et al. Fumaric and sorbic acids as additives in broiler feed. Research in Veterinary Science, v.84, p.387-394, 2008.

PLATEL, K.; SRINIVASAN, K. Digestive stimulant action of spices: A myth or reality? Indian Journal of Medical Research, v.119, p.167-179, 2004.

RICKE, S.C. Perspectives on the use of organic acids and short chain fatty acids as antimicrobials. Poultry Science, v.82, p.632-639, 2003.

RIZZO, P.V.; MENTEN, J.F.M.; RACANICCI, A.M.C. et al. Extratos vegetais em dietas para frangos de corte. Revista Brasileira de Zootecnia, v.39, p.801-807, 2010.

ROSTAGNO, H.S.; ALBINO, L.F.T.; DONZELE, J.L. et al. Tabelas brasileiras para aves e suínos: composição de alimentos e exigências nutricionais. 2.ed. Viçosa, MG, 2005. 186p.

SAMANTA, S.; HALDAR, S.; GHOSH, T.K. Production and carcase traits in broiler chickens given diets supplemented with inorganic trivalent chromium and an organic acid blend. British Poultry Science, v.49, p.155-163, 2008

SILVA, D.J.; QUEIROZ, A.C. Análise de alimentos: métodos químicos e biológicos. 3.ed. Viçosa, MG: UFV, 2002. 235p. 
SMULIKOWSKA, J.; CZERWIŃSKI, J.; MIECZKOWSKA, A. Effect of an organic acid blend and phytase added to a rapeseed cake-containing diet on performance, intestinal morphology, caecal microflora activity and thyroid status of broiler chickens. Journal of Animal Physiology and Animal Nutrition, v.94, p.15-23, 2010

TOLEDO, G.S.P.; COSTA, P.T.C.; SILVA, L.P. et al. Desempenho de frangos de corte alimentados com dietas contendo antibiótico e/ou fitoterápico como promotores, adicionados isoladamente ou associados. Ciência Rural, v.37, p.1760-1764, 2007

VIEIRA, S.L.; OYARZABAL, O.A.; FREITAS, D.M. et al. Performance of broilers fed diets supplemented with sanguinarinelike alkaloids and organic acids. The Journal of Applied Poultry Research, v.17, p.128-133, 2008.

WINDISCH, W.; SCHEDLE, K.; PLITZNER, C. et al. User of phytogenic products as feed additives for swine and poultry. Journal of Animal Science, v.86, p.E140-E148, 2008. 